\title{
APPLICATION OF SCANNING ELECTRONIC MICROSCOPY FOR METALLOGRAPHY OF WELDED JOINTS OF RAILS
}

\author{
M.G. Shtayger \\ Technical Director \\ MC Mechel-Steel \\ Moscow, Russia \\ stayger75@yandex.ru
}

\author{
V.V. Kondratiev \\ Innovative technologies \\ National Research Irkutsk Technical University \\ Irkutsk, Russia \\ kvv@istu.edu
}

\author{
A.E. Balanovsky \\ Machine-Building Technologies and Materials \\ National Research Irkutsk Technical University \\ Irkutsk, Russia \\ fuco.64@mail.ru
}

A.I. Karlina
Innovative technologies
National Research Irkutsk Technical University
Irkutsk, Russia
karlinat@ mail.ru

\author{
A.S. Govorkov \\ Management of scientific activity \\ National Research Irkutsk Technical University \\ Irkutsk, Russia \\ govorkov_as@ex.istu.edu
}

\begin{abstract}
The results of a study of the change in the microstructure of welded joints of rail steel are presented. Comparison of various methods of structural factor analysis is presented. Comparative studies of various methods of analyzing the structural factor in welded joints of $\mathrm{K76F}$ rail steels according to GOST $R \mathbf{5 1 6 8 5 - 2 0 1 3}$ are considered. It has been established that for this series of experiments, a decrease in hardness of the surface of the welded joint, as well as an increase in Barkhausen MP noise, is $65-75 \%$ of the mean value. That indicates the presence of tensile residual stresses in this zone. A coarse-grained structure of primary austenite grains with a grain score of $2 \ldots 3$ is observed along the joint line and adjacent metal layers. A solid grid of ferrite precipitates is clearly observed along the grain boundaries of the primary austenite that indicates the low plastic properties of this section. As a result of conducted studies, it was found that the microstructure of the metal in the heat affected zone of the welded rail joint after the flash welding is represented by plate and globular perlite. The change in hardness in the heat affected zone is associated with a change in the interlamellar distance of perlite that in turn depends on the cooling conditions, i.e. thermal cycle of welding. Control of the thermal cycle during butt flash welding of rails will allow one to form the optimal structure in the welded joint.
\end{abstract}

Keywords-microstructures; quenching; structure; electron microscope; perlite; ferrite

\section{INTRODUCTION}

On the railways of the world, in most cases, destruction of rails occurs because of a poor quality of welded joints of the rail joint. That is why, work to reveal the technological and metallurgical causes of non-qualitative welded joints of the rail joint [1-4] is undertaken. In most works, much attention is paid to the investigation of the cause of destruction of the welded rail [4-8]. Modern methods of electron and transmission microscopy are used to analyze the structure of the rail. It has been shown [1-8] that an increase in the mechanical properties (strength, viscosity) of the welded joint reduces the probability of failure of the welded joint. On the Russian railways, various methods of welding rails are used. Nowadays, two types of welding rails are used on the Russian rail network: electric butt and aluminum-thermite ones. Each of these species has its own spheres of application. Electric butt welding provides high physical and mechanical properties of the welded joint and is used almost everywhere on the Russian railways, with the exception of those places where the use of this welding is impossible (within the railroad switches) or where it is economically impractical). The rails entering the Russian railways are welded together by butt flash welding. Butt flash welding of rails occurs according to a scheme that consists of two stages: heating of the ends of the parts; shortening. In flash welding, heating in the contact area occurs as a result of fusion and destruction of local tie plates, formed at a certain closing speed of the contact surfaces of the rails up 
to the formation of a layer of molten metal at the ends. The second stage is accompanied by a considerable deformation of the heated surfaces as a result of a sharp increase in the compressive force of the joining surfaces, i.e. shortening.

In this paper, comparative studies of various methods of analyzing the structural factor in welded joints of $\mathrm{K} 76 \mathrm{~F}$ rail steels according to considered GOST R 51685-2013, obtained by pulsating flash butt welding and continuous welding, are carried out. This steel was chosen due to the fact that a number of highly defective welded joints of rails, detected in operation by means of flaw detection, increase year by year. Also, the number of rail fractures in the area of welded joints due to welding defects increases every year. A pronounced increase in the number of breaks due to welding defects has been observed in recent years when using in the manufacture of continuous welded railroad tracks of new grades of steels that differ in lower content of harmful impurities of sulfur, phosphorus and aluminum and the presence of impurities of copper and other non-ferrous metals.

\section{MATERIALS AND METHODS OF RESEARCH}

GOSTs were used as the basic normative documents [1-6]. To conduct the research, samples of joints of $\mathrm{K} 76 \mathrm{~F}$ rail steel after butt flash welding according to welding regimes were taken [5]. Differentiated hardening is used in rails of $\mathrm{K} 76 \mathrm{~F}$ steel, and full hardening - of steel $76 \mathrm{~F}$. The hardness of the layer, hardened by the surface of the rail head made of $\mathrm{K} 76 \mathrm{~F}$ steel is HV 374 ... 401, depth of the hardened layer varies from 7 to $15 \mathrm{~mm}$. Hardness of the base material is within HV $250 \ldots 300$. The initial microstructure of the rail steels must be sorbitol, there should be practically no separation of free ferrite (according to the requirements of GOST R 516852013). To prepare the samples, a 5-axis machining center DMG HSC75V Linear was used. To study the microrelief, Taylor Hobson Form Talysurf i200 Profilometer with computer control was used. This is a complex for the preparation of metallic materials for the study of the structure.

For metallographic studies, metallographic microscopes Micromed MET-2 and Axio Scop M2m (Carl Zeis) were used. For the microhardness measurements, Micro Hardness «Shimadzu HMV-2T» and PMT-3 were used. Study of microstructures, crystallographic parameters of the materials, the qualitative and quantitative phase and elemental analysis of substances were carried out using a two-beam scanning microscope (multi-beam system) "JIB-4500" equipped with an electron gun "LaB6". The ion gun performs the functions of a scanning electron microscope (hereinafter referred to as "SEM") and a focused ion beam (hereinafter referred to as "FIB"). Measurements of the amplitude of the Barkhausen noise (magnetic noise method of investigation) were carried out with the use of a digital analyzer "Rollscan 300".

\section{RESULTS OF THE STUDY AND DISCUSSION}

Considering the above-mentioned, before carrying out the metallographic studies, the work to measure the Barkhausen noise in the zone of thermal influence and on the surface of the welded joints was carried out. It is known that the defects (foreign inclusions, cracks), residual stresses and the microstructure influence the amplitude of the Barkhausen noise (magnetoelastic parameter, $\mathrm{mp}$ ): with the increase of the hardness and/or increase of the ferromagnetic material compression stress, the amplitude of the Barkhausen noise decreases, and a decrease in hardness and/or a increase in tensile stresses becomes higher.

In our studies, the values of mp vary in a wide range from 76 to 133 or more units, which indicates the heterogeneity of the microstructure of the metal in the heat-affected zone of the welded joint in Fig. 1 (a welded joint line is shown with a thick line). It can be seen that at points 6-10, there was a weakening of rail steel i.e. an increase of MP of the Barkhausen noise is observed. Comparison of the noise measurement results with the hardness distribution and optical metallography showed that outside the weld boundary in the heat-affected zone, large grains with the troostite structure bordered by ferrite interlayers are observed. This indicates that in this zone there were large austenite grains, that is, the rail steel was heated above the Ac3 temperature. The presence of the ferrite-cementite mixture that corresponds to the high tempering structure in the heat affected zone confirms the reduction in hardness to $2750 \mathrm{HB}$. The hardness of welded joints of the upper part of the rail web is $245-260 \mathrm{HB}$. In the heat affected zone, nature of change in hardness in the rail web is the same as in the welded joints of the rail head, and the structure of the welded joints of the rail web is coarser than that in the rail head. The hardness of the zone of the welded joints of the lower part of the web and the foot of the rail is $300-320 \mathrm{HB}$, which is significantly higher than the values of the hardness of welded joints in the head and the upper part of the rail web. It has been established that for this series of experiments, a decrease in hardness at the surface of the welded joint as well as an increase in Barkhausen MP noise is $65-75 \%$ of the mean value. That indicates the presence of tensile residual stresses in this zone. It is shown that the Barkhausen noise method in combination with X-ray methods, microstructure investigations, allows one to conduct a qualitative control of the heat affected zone of the welded rail joint.

Microstructure control with the use of electron microscopy was carried out on transverse sections in accordance with GOST R 51685-2013. It is determined that the microstructure of the base metal of rail steel is represented by finely dispersed perlite, free grains of ferrite, and ferrite-carbide mixture (Fig. $2,3)$. Distribution of ferrite grains is uneven over the area of the sample. Dimensions of ferritic grains are in the range from 5 to $80 \mu \mathrm{m}$. There are individual macro grains of ferrite 100 $115 \mu \mathrm{m}$. It should be noted that the ferrite grains, in the volume of which there are cement particles of globular or plate form, are conditionally called grains of a ferritic-carbide mixture. 


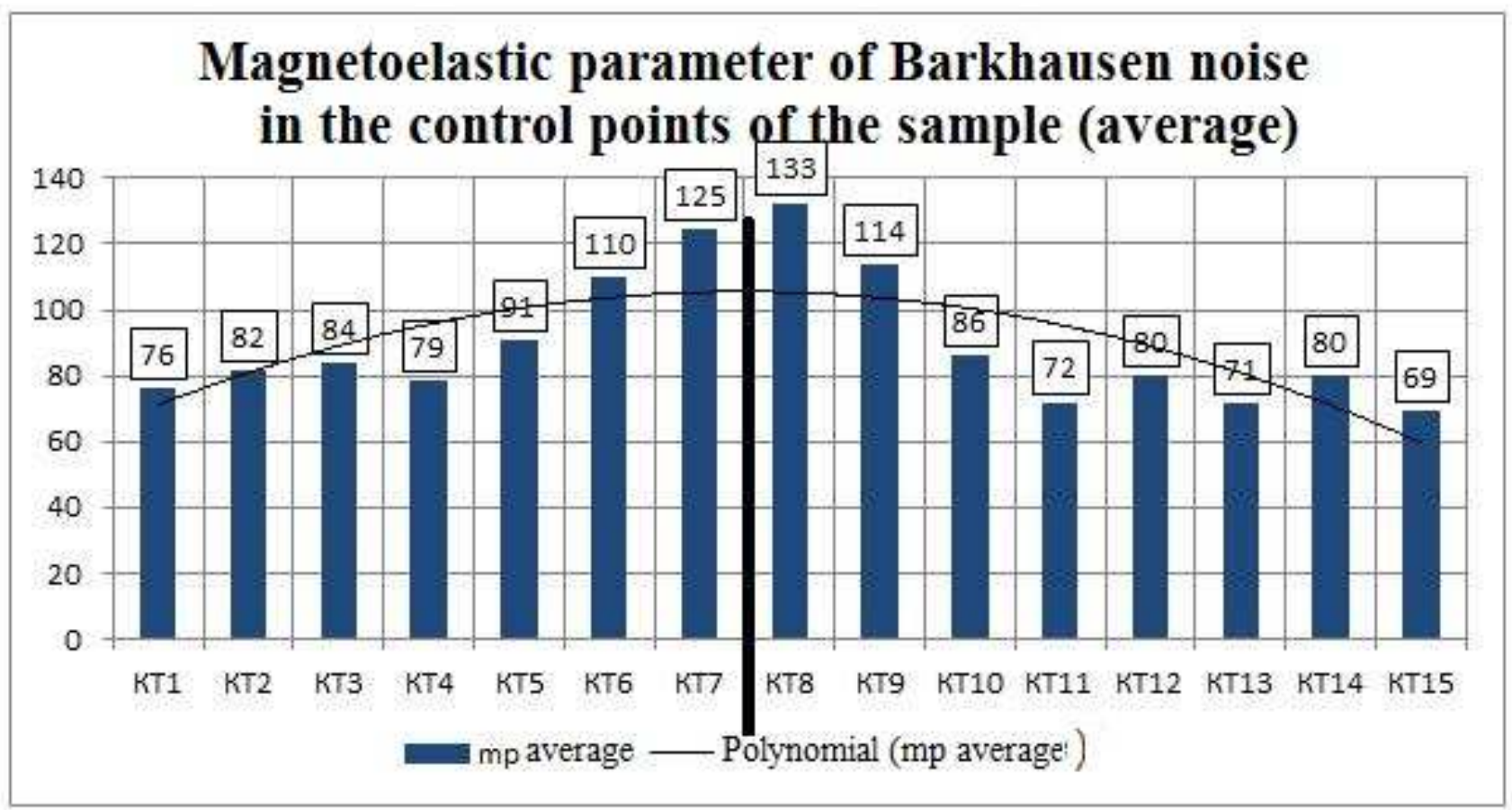

Fig.1. Results of measurements of Barkhausen noise in the heat-affected zone of the welded joint

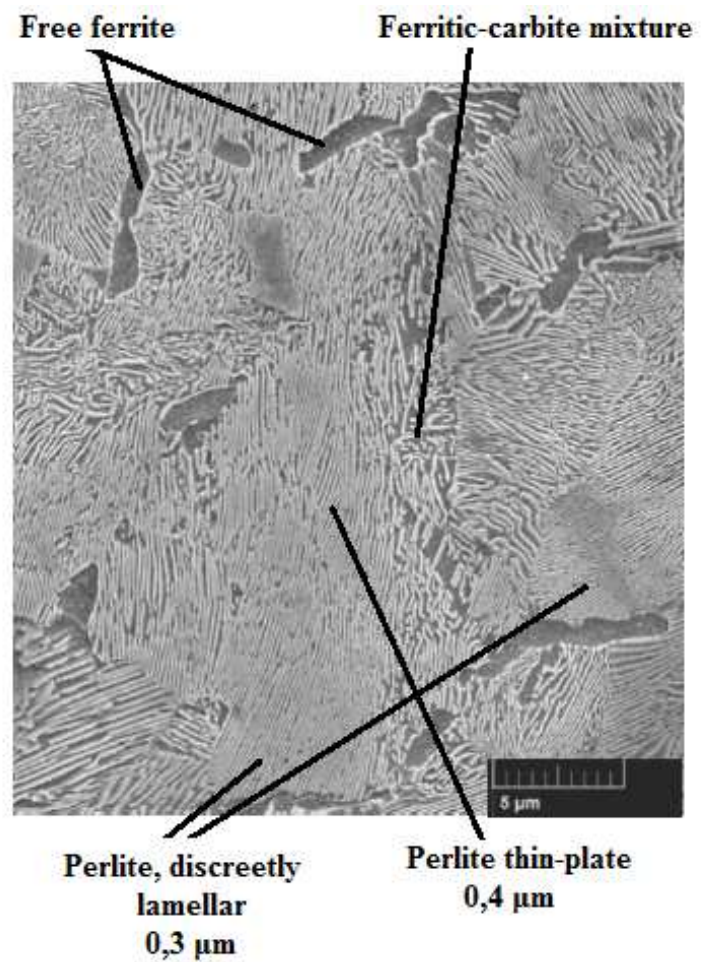

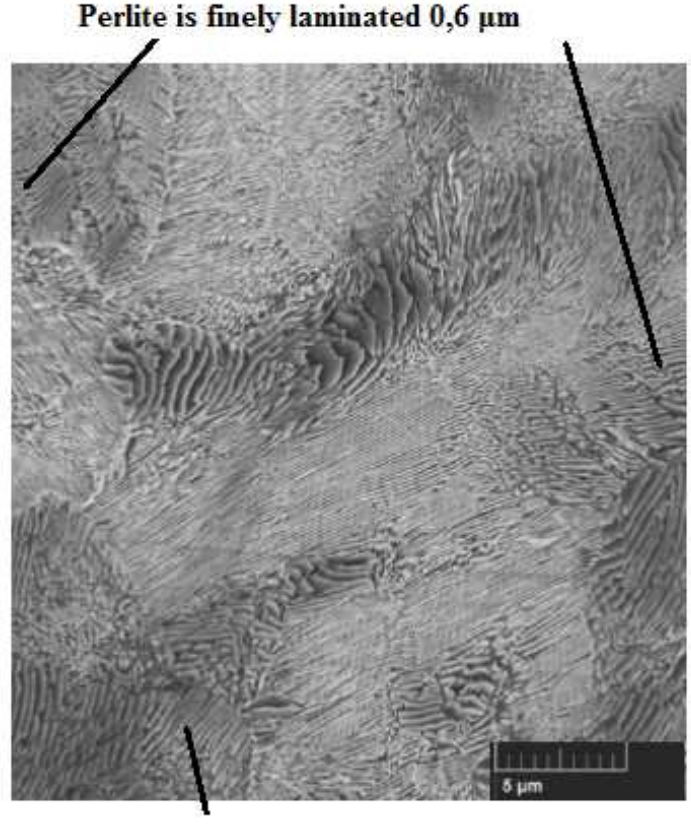

Perlite is finely laminated $0,8 \mu \mathrm{m}$

Fig. 2. An electronic photo of the microstructure in the subsurface layer of the rail head: dispersed perlite, single grains of the ferrite and ferrite-carbide mixture 


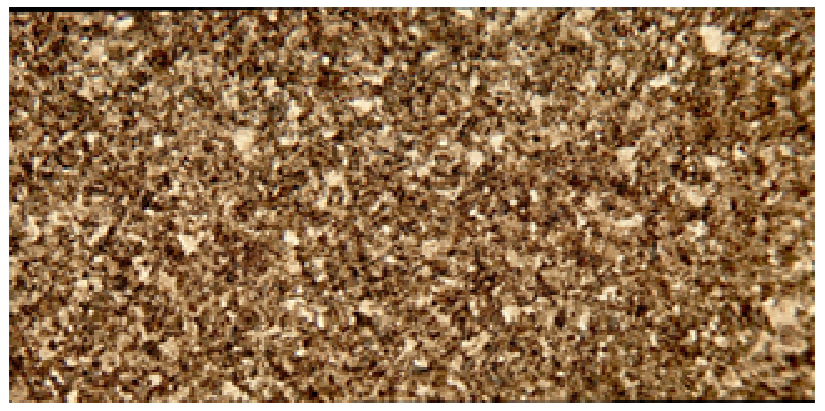

Fig. 3. A microstructure of the core: dispersed perlite and single grains of ferrite. Magnification - 100 times

According to the shape and mutual arrangement of the particles, cementite and the grains of the ferritic-carbide mixture can be conditionally divided into three subgroups. The first includes grains, in which the cementite particles are in the form of short plates. According to the morphological sign, this structure can be attributed to the structure formed by the bainitic mechanism, namely, to the upper bainite. The second subgroup includes grains in which the cementite particles of a rounded shape are randomly distributed in the bulk of the grain. It can be assumed that such grains were formed by the diffusion mechanism and are globular perlite $[6,7]$. In the third subgroup of grains, cementite particles of a rounded (globular) shape are arranged in parallel rows. Apparently, the structure of these grains was formed by a shift mechanism and is a massive martensite $[6,7]$.

It is possible to assume that in the welding process, all the features of the morphological initial structure of the rail steel that we designate will behave differently during the heating and cooling cycles. This, in turn, will affect the mechanical properties of the welded joint.

The macrostructure of the welded joint is shown in Fig.4 In the schematic representation, the uneven grain size distribution in the welded joint and the heat-affected zone is visible, which is due to the thermal cycle of welding. A layerby-layer study of the structure of rail steel in the heat-affected zone at a distance of 5-10 $\mathrm{mm}$ from the fusion zone and at a distance from it allowed us to analyze the morphology of the lamellar perlite. Even within the area of the investigation on an electron microscope, we see (Fig. 5) different characteristics of perlite by the interplanar distance criterion. In certain areas of the heat-affected zone, a mixed structure, that consists of plate sorbitol and martensitic structures [9-11] is formed. A coarse-grained structure of primary austenite grains with a grain score of $2 \ldots 3$ is observed along the joint line and adjacent metal layers.
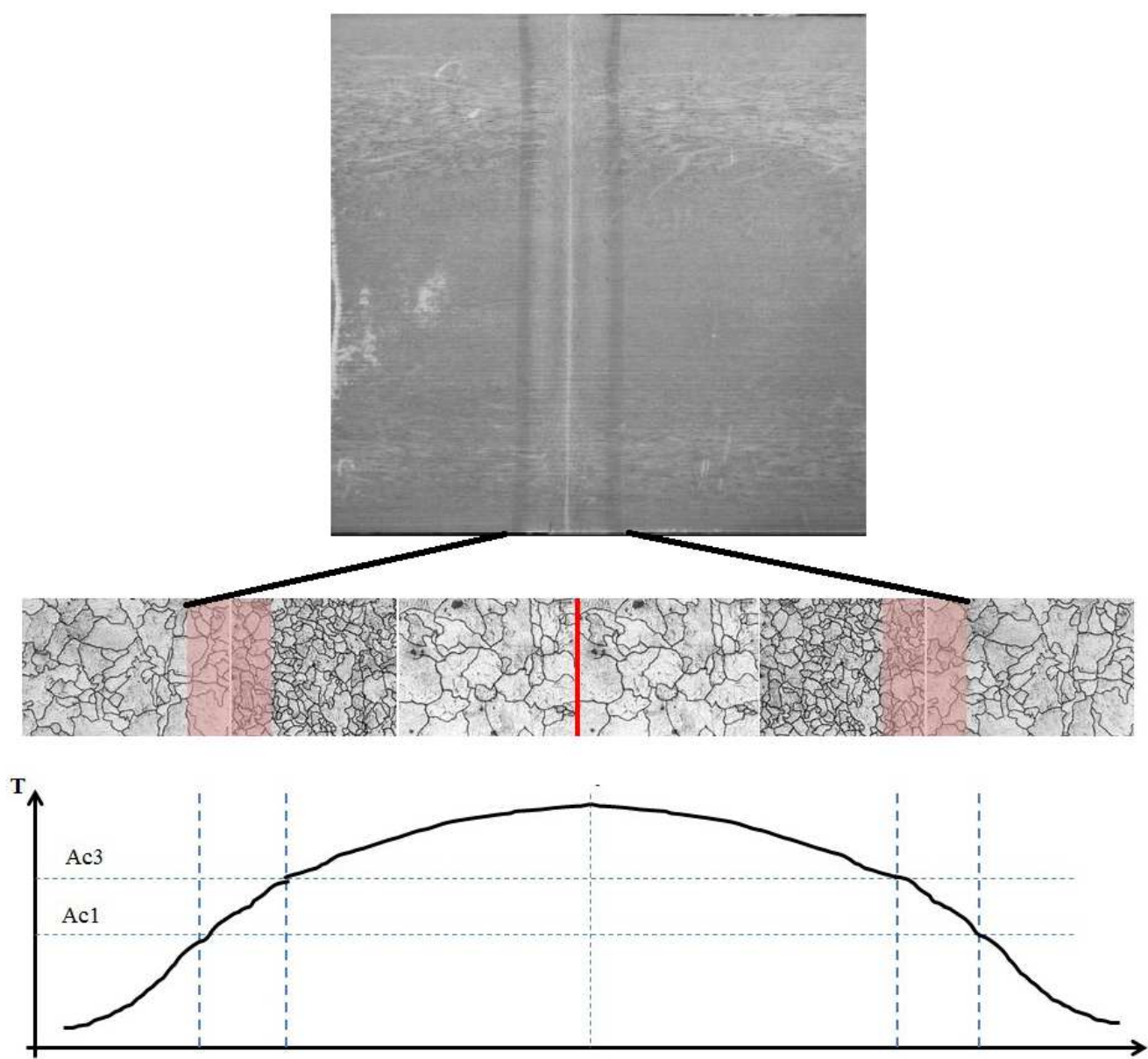

Fig. 4. The macrostructure of the welded joint of the rail joint and the schematic distribution of grain sizes in the heat affected zone 


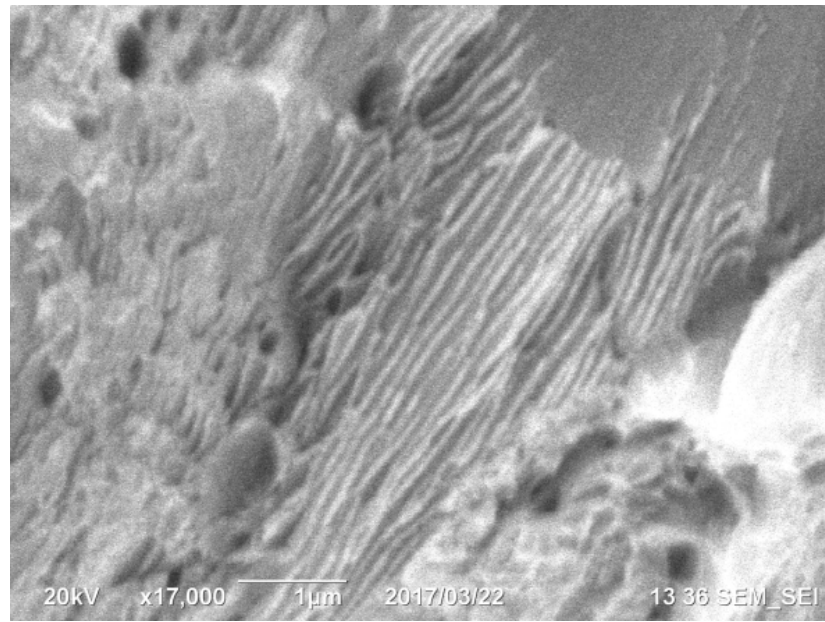

(a)

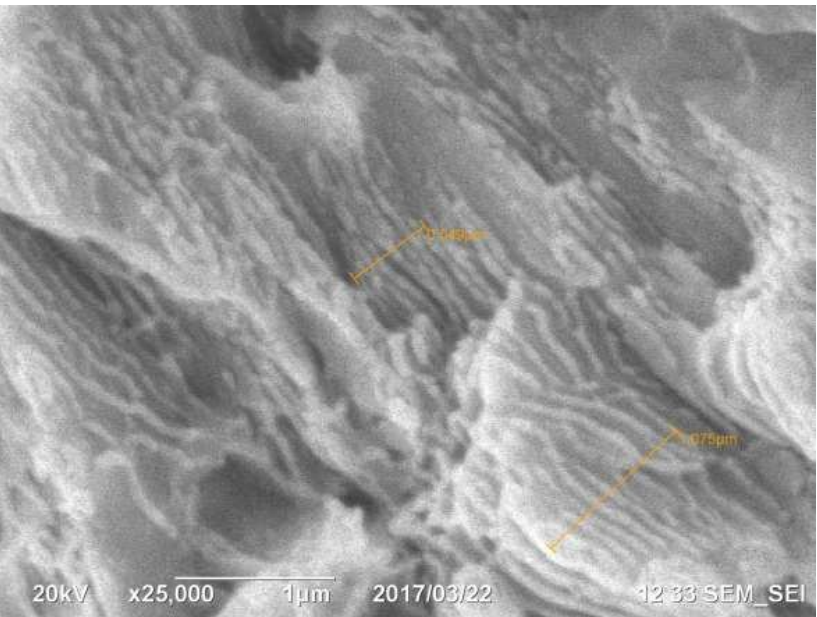

(b)

Fig. 5. Measurement of the interlamellar distance in the latently laminated perlite structure in the heat affected zone of the rail joint

A solid grid of ferrite precipitates is clearly observed along the grain boundaries of the primary austenite that indicates low plastic properties of this section. From the standpoint of welding technology [10, 12-15], namely, characteristics of the pulsating and continuous flash welding in the welded joint zone, it was found that the optimal temperature distribution in the welding zone of $\mathrm{K} 76 \mathrm{~F}$ steel rails. That provides the highest mechanical properties when testing welded rails on static bending and comparing the macrosection structure - total width of the heat affected zone during pulsating welding is half that of welding [10, 16-19].

\section{CONCLUSION}

As a result of conducted studies, it was found that the microstructure of the metal in the heat affected zone of the welded rail joint after the flash welding is represented by plate and globular perlite. Change in hardness in the heat affected zone is associated with a change in the interlamellar distance of perlite that, in turn, depends on the cooling conditions, i.e. the thermal cycle of welding. Control of the thermal cycle during butt flash welding of rails will allow one to form the optimal structure in the welded joint.

\section{References}

[1] C.Y. Xi, D.Q. Sun, Z.Z. Xuan and J.G. Wang. "The effects of flash allowance and upset allowance on microstructures and mechanical properties of flash butt welded RS590CL steel joints," Journal of Materials Research, vol. 31, Issue 24 28, pp. 3968-3980, 2016.

[2] XuemeiYu, LichaoFeng, ShijieQin, YuanliangZhang, YiqiangHe. "Fracture analysis of U71Mn rail flash-butt welding joint," Case Studies in Engineering Failure Analysis, vol. 4, pp. 20-25, 2015.

[3] U. Zerbst, R. Lundén, K.-O. Edel and R.A. "Smith Introduction to the damage tolerance behaviour of railway rails - a review," Engineering Fracture Me-chanics, vol. 76, Issue 17, pp 2563-2601, 2009.

[4] Y.D. Li, C.B. Liu, N. Xu, X.F. Wu, W.M. Guo, J.B. "Shi A failure study of the railway rail serviced for heavy cargo trains," Case Studies in Engineering Failure Analysis, vol. 1, Issue 4, pp. 243-248, 2013.
[5] U. Zerbst, M. Schödel and R. Heyder. "Damage tolerance investigations on rails," Engineering Fracture Mechanics, vol. 76, Issue 17, pp. 2637 2653, 2009.

[6] N.K. Mandal. "On the low cycle fatigue failure of insulated rail joints (IRJs)," Engineering Failure Analysis, vol. 40, pp. 58-74, 2014.

[7] N.K. Mandal. "Ratchetting of railhead material of insulated rail joints (IRJs) with reference to endpost thickness," Engineering Failure Analysis,vol. 45, pp. 347-362. 2014.

[8] A.A. Nikulina, A.A. Bataev, A.I. Smirnov, A.I. Popelyukh, V.G. Burov and S.V. Veselov. "Microstructure and fracture behaviour of flash butt welds between dissimilar steels," Journal Science and Technology of Welding and Joining, vol. 20, Issue 2, pp. 138-144, 2015.

[9] GOST R 51685-2013. Rel'sy zheleznodorozhnye. Obshchie tekhnicheskie usloviya.

[10] TU 0921-326-01124323-2015 "Rel'sy zheleznodorozhnye tipa R65 kategorii DT350 i DT350SS proizvodstva OAO «CHMK», svarennye ehlektrokontaktnym sposobom".

[11] GOST 10243-75 (ST SEHV 2837-81) Stal'. Metody ispytanij i ocenki makrostruktury.

[12] GOST 1778-70 (ISO 4967-79) Metallograficheskie metody opredeleniya nemetallicheskih vklyuchenij.

[13] GOST 8233-56 Stal'. Etalony mikrostruktur.

[14] SongDing , PingWang, YangLin, Dingyi Zhu. "Reduction of thermal effect on rail stress measurement based on magnetic Barkhausen noise anisotropy," Measurement,vol. 125, pp. 92-98, 2018.

[15] EN 15305:2008. Non-destructive Testing. Test Method for Residual Stress analysis by X-ray Diffraction.

[16] V.E. Gromov, A.B. Yur'ev, K.V. Morozov, YU.F. Ivanov Mikrostruktura zakalennyh rel'sov. Novokuzneck: Inter-Kuzbass, 2014, 213 p.

[17] V.E. Gromov, K.V. Volkov, YU.F. Ivanov, K.V. Morozov, S.V. Konovalov and K.V. Alsaraeva. "Struktura, fazovyj sostav i defektnaya substruktura rel'sov vysshej kategorii kachestva," Izv. vuz. Fizika, vol. 2. pp. 72-76, 2014.

[18] M.G. Shtajger, N.N. Ivanchik, A.I. Lisicyn and A.I. Karlina. "Ispol'zovanie metodov skaniruyushchej ehlektronnoj mikroskopii dlya metallografii rel'sovyh stalej," Sovremennye tekhnologii. Sistemnyj analiz. Modelirovanie, vol. 4 (56), pp. 189-196, 2017.

[19] A.E. Balanovskij, M.G. Shtajger, V.V. Kondrat'ev and A.I. Karlina "Kompleksnye metallograficheskie issledovaniya stali 110G13L posle termoobrabotki," Metallurgiya: tekhnologii, innovacii, kachestvo, vol. 2, pp. 154-159, 2017. 